\title{
Prítomnost ženského princípu v prózach D. M. Anocovej
}

\author{
Patrik Šenkár (Komárno)
}

\begin{abstract}
Abstrakt
Príspevok poukazuje na existenciu Slovákov na Dolnej zemi so špecifickým zretelom na Rumunsko. Zvýrazňuje a adekvátne pertraktuje rôzne okolnosti, ktoré sú neodmyslitel'nou zložkou svojbytnosti národa či národnosti. Všíma si konkrétne atribúty, ktoré plnia utvrdzovaciu úlohu a funkciu pri zachovávaní národného povedomia Slovákov v Rumunsku. $\vee$ jednotlivých interpretovaných (literárnych) dielach sleduje aj motíry, ktoré tematicky smerujú k širším súvislostiam. Analyzuje dve prózy Dagmar Márie Anocovej, všestrannej osobnosti slovenskej kultúry súčasného Rumunska. Na základe objektívno-subjektívnych postrehov či báz čitatel'skej skúsenosti v rámci interpretačných postupov - uvádza a konfrontuje (ne)l'ahký život najmä ženských postáv. Poukazuje na ich spletité osudy v rámci rôznorodých spoločensko-psychologických vztahov vo svete dospelých.
\end{abstract}

\section{Kl'účové slová}

Slováci v Rumunsku; národnostné bytie; interpretácia; prozaická výpoved'; ženský aspekt

\section{Abstract \\ The Presence of the Principle of Women in the Prose of D. M. Anocová}

The article points to the existence of the Slovaks in the Lowland with a special regard to Romania. In addition, it highlights and adequately discusses the various circumstances which are an indispensable component of the uniqueness of a nation or nationality. It looks at specific attributes that fulfill the assertive role and function of maintaining the national awareness of Slovaks in Romania. In the various interpreted (literary) works, the themes are thematically oriented towards the wider geographical broader context, are also observed. The paper analyzes two prosaic books of Dagmar Mária Anocová, a versatile personality of the Slovak culture of present Romania. Based on objective-subjective views or the basics of reading experience in interpretive procedures, it presents and confronts the more or less easy life of female characters. It points to their complex fates within the diverse socio-psychological relationships in the adult world.

\section{Key words}

Slovaks in Romania; ethnic identity; interpretation; prosaic testimony; female aspect 
V súčasnom období sme svedkami permanentného poklesu literatúry ako mienkotvorného segmentu kultúry. Kultivovanosţ človeka a jeho kultúrne vedomie v novom miléniu sa podiela na vytváraní hodnôt menej, ako by si to vnímavý zoon politikon želal. Esteticko-poznávacie hodnoty súčasného človeka sú rôznorodé a rozptýlenejšie ako dakedy. Literatúra by pritom mala byt’ problémovou reflexiou života, ktorá núti premýšlat', spoluvytvárat' a dotvárat' - teda (aj) interpretovat'. Nemôže preto „... hl'adiet' l'ahostajne na morálne problémy súčasnosti - globálne a individuálne, na oslabovanie identity jednotlivca i kolektívu, na redukovanie historického vedomia [...] nemôže ju netrápit’ celkový pokles kultúrnosti, pokles estetického vedomia, ale aj absencia kritickosti, diskusnosti..." $\mathrm{O}$ tom je vlastne práca s textom; o tom je interpretácia.

Táto myšlienka významného literárneho vedca Rudolfa Chmela gradovane platí v prípade autorov z radov národnostnej menšiny, $\mathrm{v}$ našom prípade autorky zo súčasného Rumunska: Dagmar Márie Anocovej², ktorá dodnes publikovala „iba“ dve knihy próz ${ }^{3}$ (popri viacerých básnických zbierkach i literárnovedných publikáciách a nespočetnom množstve literárnokritických textov atd'.).

Prozaická knižná prvotina autorky s názvom Kniha príbehov alebo poltóny obsahuje tri širšie koncipované texty s rôznorodými (najmä ženskými) osudmi. Autorka v nich vo všeobecnosti využíva realistické zobrazenie skutočnosti, uvádza komplikovanost l’udských vztahov.

V prozaickom texte (Skúška) prízvukuje dôležitost̉ stretnutí, a to na epickej línii cestovania mladej rozvedenej novinárky na skúšku z filozofie počas externého vysokoškolského štúdia. Do kontrastu kladie racionalitu s citovostou a romantickými myšlienkami. Prízvukuje determinovaný ludský údel nezmierit sa so stavom šedej myšičky a nepremenit’ sa na jednoduchú bytost': „... nemali by sme dovolit', aby sme sa zmenili na čierne a biele skalky, gul'ky, ktoré sa skotúlajú raz sem, raz tam. Ale t’ažko je bojovat' proti silám, ktoré v nás bublajú a niekedy si ich ani len pomenovat' nemôžeme..."(s. 6). Dôležité je teda nájst̉ práve

1 CHMEL, Rudolf: Spoločnost’ a život literatúry. In: Romantizmus v globalizme. Bratislav: Kalligram, 2009, s. 215. (Celá esej sa nachádza na stranách 212-215 a pôvodne bola publikovaná ako úvodník v Slovenských pohladoch pri príležitosti nástupu nového šéfredaktora Rudolfa Chmela v januári 1988. Bližšie: Slovenské pohlady 104, 1988, č. 1, s. 2-5.)

2 Za mimoriadne dôležité pokladáme prízvukovat, že najmä z kvantitatívnych dôvodov neuvádzame životné osudy a tvorivé metódy/impulzy tejto osobnosti slovenskej kultúry či literárnovedné a literárnokritické ohlasy na dve postupne jej analyzované knihy próz. Tieto aspekty sú zahrnuté do nášho konferenčného príspevku, ktorý odznel v rámci medzinárodnej vedeckej konferencie. O tom bližšie pozri: ŠENKÁR, Patrik: Večné a podobné zrkadlenia „rozprávkového“ sveta „stredoeurópskych“ deti v intencionálnych prózach D. M. Anocovej a J. Nováka. In: POSPÍŠIL, Ivo (ed.): Střední Evropa včera dnes: proměny koncepcí II (jazyk - literatura - kultura - politika - filozofie). Brno: Středoevropské centrum slovanských studií, 2018.

3 Máme na mysli knižné prozaické publikácie: ANOCA, Dagmar Mária: Kniha príbehov alebo poltóny. Bukurešt: Kriterion, 1988; resp. ANOCA, Dagmar Mária: Zväčšenina. Nadlak: Vydavatel'stvo Ivan Krasko, 2001. Za konkrétnymi úryvkami v našom texte upresňujeme „iba“ patričnú konkrétnu stranu z pôvodiny. Všetky úryvky sú z knihy Kniha príbehov alebo poltóny, okrem posledných siedmich, ktoré sú z knihy Zväčšnina. Okrem toho si uvedomujeme aj určitý časový odstup od vydania tejto knihy (1988). Konfrontujeme ju však s druhou spomínanou knihou z roku 2001. Aj z toho dôvodu nie je náhodný úvodný citát práve z roku 1988... V minulom roku (2018) sme si teda pripomínali 30. výročie týchto udalostí: lebo vydanie tejto prózy bola v slovenskej literárnej tvorbe v Rumunsku skutočnou udalostou, taktiež ako odchod starého a príchod nového šéfredaktora Slovenských pohladov... 
v domácom prostredí spriaznenú dušu (rezerva pre city, venovat’ pozornost'), lebo človek „... nemôže predsa po celý život bežat' sám ako divoký vietor, treba sa mu pripútat’ o čosi, o kohosi“ (s. 23). V príbehu je teda evidentný určitý útek od minulosti, ale aj prítomnosti. Z týchto dvoch entít potom „vyhráva“ tradícia, ktorá sa chápe ako synonymum poriadku. Úzkost', stiesnenost', bezmocnost̉ nespokojnej (ženskej) duše túži odpútat’ sa od prízemnej prítaže problémov. Tento pocit sprevádza tajná viera po dosiahnutí svojho vytúženého l'udského ciel'a s konkretizovanou snahou zblížit sa s niekým a doslovne sa mu vyžalovat'. Aj hlavná hrdinka sa aktuálne dostala do istého intermezza, ked' v poslednej dobe „... prestali ju zaujimat' ini, vyrušovalo ju, ked' cudzi l'udia prejavovali záujem o ňu“ (s. 8).

Určitá zatrpknutost̉ (až depresia) moderného človeka v postmodernom svete sa u hlavnej protagonistky prejavuje odcudzením od dovtedajšieho sveta a dvojakého života. Silou-mocou túži po stretnutí, po novom duševnom dobrodružstve. To náhodne (existujú vôbec náhody?) prichádza počas cesty (od príčiny k ciel’u) v podobe postupného zbližovania s cudzím mužom - spolucestujúcim. V ich kontakte sa zhmotňujú rôzne stupne komunikácie a vyúsţujú až do pozvania na večeru. V duševnom stave ženy je určitá nerovnováha: strach a obava stojí v protiklade s vytúženým pocitom dat sa unášat osudom: „Chcela byt’ obyčajným, drobným človekom, ktorý si môže robit to, za čo hodlá zodpovedat’ a za čo unesie zodpovednost" (s. 10). Jej duševný stav je však sínusoidný: stále porovnáva nových ludí s bývalým manželom. To ju brzdí pri zabúdaní na minuloste a nedovolí získat̉ duševnú vol’nost'. Autorka prízvukuje však (určité) prímerie mužského a ženského princípu ako jeden z determinantov neúnavného kolobehu života na báze rodovej rovnoprávnosti: „V živote sa stále čosi musí diat'. Nemožno z neho vystúpit, nemožno sa ho vzdat', nemožno zostat'vedl'a utekajúceho rýchlika, musime bežat's ostatnými d’alej, sami sebe dat' šancu, dat' ju i druhým“ (s. 14). Treba teda mat’ prístrešie pred víchricami doby (dom i muža). Tým sa spoločensky socializuje a vytvára sa pre ňu kardinálne puto: „Len preto som človek, že som pol’udštený vzt’ahmi. Čistý človek je ako piesok vyvrhnutý na breh oceána“ (s. 15). Na základe toho sa v príbehu zdôrazňuje aj potreba výberu jasných stránok života, s ktorými citlivý človek pomôže sebe i svojmu okoliu. Týmto procesom získavania pocitu istoty sa určite nenarúša dôležitá podstata človeka: jeho svedomie.

Na dráhe tejto duševnej cesty časom i miestom (iný kraj, iný mrav; „zázračný“ svet dospelých) je pre psychicky pevnú osobnost̉ dôležité uvedomit’ si plynutie času na vlastnej koži a zmierit sa s vlastným osudom: „Nakoniec človek si musí robit’ svoju robotu tam, kde ju má. Kde je načim“" (s. 28). V texte sa vyskytuje aj kritika doby, najmä kvôli nedostatku času pre vážne rozhodnutia, vždy prítomnú psychologizáciu každého konania inteligentného človeka. Táto cesta je však vydláždená neustálym prehrabávaním sa v spomienkach, ktoré vedú k bezvýznamnosti a koniec koncov k smrti. Tá sa prejaví infarktom muža, s ktorým určitý čas mladá novinárka zažila to podstatné, čo robí človeka človekom...

Dôležitým príznakom (ba základom) bytia je potreba vzájomnej komunikácie v spletitých osudoch ludského života. V autorkinej širšie koncipovanej próze Rovnováha sa opät pertraktujú pocity mladej ženy a l’udská práca ako prostriedok na zabúdanie. Túžba prekonat̉ minulost' (a tým vlastne aj sám seba) sa však hatí pocitom menejcennosti mladej vysokoškoláčky Zuzany. Chce sa prispôsobit súčasnému svetu a mikroprostrediu, čo sa v konkrétnom texte spredmetňuje radostou z každej chvíle života. Podstatou problémov 
ženskej duše je tu konfrontácia predstáv mysle a reality sveta s neustále sa tvoriacou realitou nového sveta: „My musíme priestor oslobodit’ od zbytočného, nefunkčného pátosu ako od okov, od nánosu starých storoči [...] nám prichodi vyjadrit’ nový životný pocit, elán, radost', jas, čistotu“ (s. 71). Významným okamihom v príbehu je stretnutie mladej slečny s asistentom vysokej školy a jeho prosba o pomoc pri rozpracovaní technického projektu. Z čitatel'ského hl'adiska je dôležitý postupný psychický vývoj (od odmietnutia až po sympatie k mužovi). Tým sa vlastne postupne odbúrava vzdialenost̉ duší, ktorú autorka vysvetluje ako nenormálnu a netypickú pre dnešnú dobu bezcitnosti. Práve Anocová je tou, ktorá svoj text rámcuje klasickým námetom v trojuholníku: dobrosrdečná, ale trošku l’ahkovážna spolubývajúca, tvrdá, dôkladná, ale postupne poddajná vysokoškoláčka a mladý fešák-asistent s nie vždy najúprimnejšími myšlienkami a želaniami. Stavia do kontrastu idealizmus s realizmom, neskúsenost̉ so skúsenostou ako podklad na psychologický ponor do vlastného vnútra (Čo vlastne chcem?). Zuzana ako idealistka, neskúsená, ale s výdržou, vôlou a presne dáva dôraz na dôležitost' stretnutí s významným mužom. Tento vnútorný „boj“ je dokreslený aj dôležitostou oblečenia, určitou pracovnou intimitou, diétou, udržiavaním kondície cvičením - teda pripravenostou na všetky možné varianty vo vývine situácie. Jej túžba však stroskotá na chladnosti, prehnanej objektivite a tajnostkárstve mladého asistenta. Spolubývajúca sa jej snaží „otvorit oči“ a priučit’ ju k tomu, ako to vlastne na svete chodí: „... ešte vždy si myslǐs, že môžu byt’ aj takéto priatel'stvá, ale uvidiš ty ešte, ako to beži na svete, len ti bude pozde, na vlastnej koži skúsiš..." (s. 47).

Nerozhodnosṫ mladého človeka v každodenných veciach vzniká z nadštandardného psychického stavu. To vedie až k filozofujúcim myšlienkam hlavnej hrdinky (aj) o vlastnom „túlaní sa“ v čase a priestore: „Rozčul’uje ma obmedzenost' mojej existencie, l’udského údelu. Nemožnost’ dosiahnut' realizáciu možností. Že som zavretá v sebe, vo svojej dobe, vo svojom úzkom priestore. Rada by som napriklad bola aj nebola [...]. Chcela by som cestovat'v čase, vrátit' sa dozadu [...]. Chcela by som tu zostat' a byt' neviditel'ná, ale jestvovat' pritom; chcela by som tu zostat' aj po smrti“"(s. 54-55). Dôležité je teda hladanie istôt v ludskom živote, základ na odbúranie komplexov a zábran: „... sme v určitom zmysle zajatci svojho času a priestoru, klbká rôznych návykov, obyčaji, mentalít, ktoré navinuli naši vychovávatelia..." (s. 106). Týmito kladnými nánosmi civilizácie a l'udskej empírie sa cibrí jednotlivec. Dôležité sú teda okrem činov aj myšlienky a city. V pozadí chápania seba samého je dôležité porozumiet aj svojmu okoliu (tzn. tahat’ v spoločnosti za jeden povraz a chápat život vlastne ako hru na vážne veci).

Podstatným determinantom nášho bytia je čas. Autorka prízvukuje súčasné zrýchlené tempo doby, kde my - l’udia sme akosi zmeškaní. Zdôrazňuje potrebu, „... aby sme lepšie žili, aby sme boli lepši k sebe, aby sme l'ahšie a skôr naučili deti životu..." (s. 60). Čas je práve tým faktorom, ktorý pomáha fyzicky i duševne stat’ sa nezávislou osobnostou, čo je však determinované konformitou k spoločenským podmienkam i osobám. Zuzana sa postupne oboznamuje s každodennou realitou (šedou, chudobnou na impulzy) a potvrdzuje svoju empíriu o jednotvárnosti fyzickej či psychickej samoty súdobého jednotlivca. Osobnosti s vlastnými postojmi a názormi táto doba ničí. Na druhej strane je však potrebná osožnost’ človeka: slúžit lud’om a byt vyrovnaný sám so sebou, všímat si svoje okolie, upevňovat’ pocit spolupatričnosti a ducha kolektívnosti, lebo „... každý má svoju úlohu, 
každý je niečím nepostrádatel’ný, potrebný na istom mieste zložitej mozaiky života“ (s. 68). Spomínané akoby odstredivé sily ukazujú ako centrálny pojem a ciel’ týchto snažení umenie, ktoré kladie práve človekove otázky svetu; je oslobodzovaním a potvrdením samotnej l’udskosti. Aj v tomto spojení individuálneho poslania (vd’aka najvšeobecnejšiemu chápaniu umenia) sa prízvukuje kolektivita: „Chceš slúžit’ l’ud’om svojím umením. Nemôžeš to robit’ sám. Potrebuješ mat'okolo seba priatelov, spolupracovnikov, pomocníkov, l'udí, ktori t'a majú radi a na ktorých sa môžeš obrátit" (s. 74). Dôležitá je individualita so skrytými možnostami (najmä v mladosti), ktorá sa upevňuje v interakcii s ostatnými osobami v kolektíve. Významné negatívne psychické stavy (ohúrenie, bezradnost', zarazenost', poníženost', zahanbenost') sa dávajú do kontrastu s doslovne dobrým, až nereálnym svetom. Prevyšovanie mužského princípu nad ženským (azda) podl’a spoločenskej konvencie sa spredmetňuje Zuzaniným sklamaním v asistentovi (využíval jej prácu na získanie štipendia do zahraničia pre seba). V texte sa prízvukuje mužské pokrytectvo a opätovná práca bez pláce s konkrétnym využitím ženskej citlivosti. Spomínaná nekonečná túžba človeka po pokojnom živote (aj napriek negatívnym vplyvom okolia) sa deklaruje využitím už spomínanej dostredivej sily, určitou vyváženostou, nachádzaním zmierenia pre seba a nosením pokoja v sebe: „Vo svete niet dobra ani zla. Len medzi l'ud’mi jestvuje zlo, ak mu dovolia rozpinat' sa..."(s. 76).

Pocit neistoty (až strachu), vychádzajúci zo samoty a komplexov, sa zhmotňuje určitým očakávaním muža aj po pracovnom rozchode. Uvedený čas však „zasiahne“ a city prirodzene vyhasínajú, až vyblednú aj obrazy. Neistota sa však dramatizuje prísnym pôvodným domácim (dedinským) prostredím Zuzany a jej morálnym poklesom (tehotenstvo). Na druhej strane sa však prízvukuje právo každej ženy rozhodovat o vlastnom osude. Život hlavnej hrdinky je tak primerane veku rozhojdaný: od komického k tragickému a opačne, od epického k lyrickejšiemu a spät. Táto oblúkovitost’ vrcholí návštevou u lekára (potrat): práve tu sa koncentruje jej nenávist’ voči sebe, okoliu, prostrediu, situácii: „Zdalo sa jej, že sa viac sem nevráti. Odíde niekam, odkial’ niet návratu. Hnusila sa samej sebe..."(s. 89). V tomto vel'mi dôležitom životnom rozhodnutí sa strieda spomínaná túžba po návrate do minulosti a premeny jej života smerom do budúcnosti. Postupná socializácia a vytváranie vzt’ahov s inými mužmi (samozrejme, najprv s odstupom, chladom, vykaním a až potom prirodzenou ženskou márnivostou) deklaruje potrebu vyjst̉ zo svojej škrupiny. Preto je dôležité uvedomit si vlastné rezervy, lebo „...v každom človeku sú skryté aj nesmierne bohatstvá, len ho treba naučit’ stále ich v sebe objavovat'. Niet silnejšieho na svete, ako je drobný človek..."(s. 98-99). Dôležitou súčastou nášho bytia je teda neustále mysliet̉ na budúcnost', dosiahnut vnútornú rovnováhu a zachovat si čo najväčšiu fyzickú i psychickú samostatnost': „... potrebujeme viac, d’alej, myšlienky, ktoré nám prebojúvajú budúcnost', ako žit'v ňom zajtra, ako rozvijat' náš svet napozajtra, ako riešit' jeho konflikty a ako sa im vystríhat', pestovat' ho ako rastlinku, čistit’ ho ako strom od parazitných nánosov a prežitkov" (s. 105).

Dôležitou entitou človeka je triumvirát slobody - poznania - výberu, ked' v súlade s francúzskymi existencialistami máme „... právo výberu, právo poznania, v tom je naša sloboda, hodnotit', priat' alebo zatratit', preto musís poznat' aj také veci, ktoré sa ti zdajú neužitočné..." (s. 99). Lineárnost’ a prirodzené plynutie času (ale aj psychického vývinu jednotlivca) potvrdzujú nové stretnutia a zblíženia (aj Zuzka sa stretne s novým kolegom z práce - s exotickým černochom, pri ktorom duševne omladne po neradostných 
životných skúsenostiach). Príval novôt je teda v našom živote zabezpečený; dôležité je však snažit sa zostat človekom: komunikovat', patrit’ k niekomu a mat rád prostredie, z ktorého človek vyšiel. Sú dôležité neustále impulzy z nových okolností života a nových (kladných) návnad osudu bez pochybností. Dôležité sú aj ochranné krídla tradície, ktoré v spojení so spomínanými entitami sú schopné zabezpečit duševný pokoj aj počas putovania po jedinej možnej ceste, t. j. ceste životom.

Autorka v d’alšej próze Cesta opisuje s určitým odstupom prívetivú, väčšmi citlivú než racionálnu mladú ženu Ivetu - približne tridsatročnú vysokoškolskú pedagogičku s relatívne vel'kou dcérou a manželom - fyzikom. Jej bývanie s rodičmi, zhasínajúci vztah s manželom a nemilosrdné správanie sa spoločnosti dovedú mladú protagonistku až k šedému vnímaniu celého okolia, nakol'ko „... sa postupne aj Iveta priučila elegantnému správaniu, spoločenskej konverzácii a pohybovat' sa lahodne, ladne pred zvedavými hodnotiacimi zrakmi l’udi..."(s. 131). Chrbtovou kostou celého sujetu je dôraz na dôležitost’ náhlych (aj ked' krátkodobých) rozhodnutí v živote. Tie sa konkretizujú odchodom mladej protagonistky z vlastného zažitého prostredia. Je to teda cesta spomínaná v názve - pohyb, útek ako určitý únik od stereotypov a napätia. Je to ako jedna železničná kol’aj pri ceste, ktorú má nárok využívat každý pri obnovovaní vlastného ja. Autorka prízvukuje potrebu odíst od životných konštánt a samozrejmostí (Iveta sa rozhodne cestovat ku kamarátke na dedinu - rozptýlit’ sa, psychicky vypnút). Dôležitý znak je spoznanie nemennosti (aj nového) prostredia, čo sa prejavuje evidentnou zaostalostou dedinského prostredia v pomere k životným podmienkam samotnej Ivety (tažko zohnat aj kávu, šetrí sa na verejnom osvetlení ulíc a pod.). Do kontrastu sa teda dostáva konkrétne (i symbolicky) mestské a dedinské prostredie (koruny agátov a sliviek; dolnozemský morušový sad, ktorý vysadila obec i škola, naproti tomu bezciel'nost’ uponáhlaného života v meste). Iveta sa prispôsobí novému mikrokolektívu aspoň dočasne aj vd’aka postupným opätovným stretnutiam so starými priatel'mi a prostredím. Jednotlivé l’udské duše sa jej otvárajú aj vd’aka vzájomnej prívetivosti. V situácii tažkého rodinného života (najmä trápenie s manželom) sa zdôrazňuje životná múdrost', že nemožno súdit nikoho. Zaujímavým psychologickým aspektom je však oblúkovitost' Ivetiných pocitov a jej postupné duševné odcudzenie aj z tohto priestoru (ani na dedine sa nič nezmenilo, ludské charaktery sú konštantné, nenachádza predpokladanú idylu): „Vel’mi l’utovala, že sem prišla [...] miesto vidieckej pohody, ktorú by si bola želala, musela stŕpat', čo povie, aby nebodaj niekoho neurazila“ (s. 141). Nadštandardne je teda prítomný psychologický moment (najmä u ženských postáv), prejavujúci sa oživením vlastnej pamäti až do detailov, zahanbením sa pred sebou samou, vynaložením enormne vel'kej duševnej sily kvôli udržaniu manželského vzţahu ako určitej obety. Do tohto vlastne genderového bytia vnáša prvky aj lúbostný motív z minulosti, ktorý teraz ničí toto stretnutie od základov. Zdôrazňuje sa pri tom vyšší princíp racionálneho priatel’stva, ktoré si treba vážit, ale nebyt’ jeho otrokom.

Zaujímavá postava je aj Ivetina kamarátka Eva, osoba plná očakávania voči manželovi, Ivete i svetu. V jej konaní a myšlienkach je vyjadrená trpezlivost̉ manželky a túžba zachránit’ vztah. Vplyv okolia na Evu však dopadne ambivalentne a jeho výsledkom je váhanie na báze širších myšlienkových pochodov. Je však popretkávané ilúziami, túžbami a všemožnou nádejou mladej ženy: „Aj zli l’udia potrebujú nehu. Každá bytost'. A ako ináč môžeš 
človeka premenit’ na človeka, čiže na dobrého, ak nie nehou a trpezlivostou?" (s. 149). Potrebná empatia ženských postáv, okorenená solidaritou v opozícii s mužským princípom, sa spredmetňuje vo všeobecne platnej kritike mužov (alkohol, hrubost’, bezcitnost'): „... aj ja sa tak vnútorne striasam. Ako by som chcel zo seba zhodit’ osud [...]. A nedá sa to [...]. Hrozný je pocit bezmocnosti..." (s. 164). Pre citlivého človeka sú teda vzácne aj kladné duševné pochody, ktoré prinášajú opojné utišujúce potôčiky do l’udského vnútra. Ich nenájdenie spôsobí zmenu citlivej l’udskej psychiky, ktorá aj vplyvom doby, skúseností, okolia, užšej a širšej rodiny vyústuje až do pocitu skepsy: „Všetkého som sa vzdal. Všetkého, čo oslobodzuje ducha, človeka robi lepšim“ (s. 159). Postavy v zásade konajú v určitom negatívnom afekte, ktorý je determinovaný pesimistickým pocitom znechutenia znova sa učit životu a správat sa v ňom lepšie. V tom prípade treba na zlepšenie tohto stavu spájat’ minulost', prítomnost a budúcnost’ a mat taký potrebný optimistický pohlad na svet z dôležitého pocitu nepremárnenia životných šancí, t. j. túžit po vyváženosti a celkovom komplexnom poriadku: „Čo je to oddychovat? Vždy som musela niečo robit'. A nechcem mat' ani l'ahký život. Chcem ho mat’ usporiadany“"(s. 148). Postavy sú teda odhodlané zmenit svoj život, ktorý sa však často nevie pretavit do konkrétnych činov. V inom - dedinskom - prostredí vznikne pocit u mladej Ivety vrátit sa domov, ktorý tak vyjadruje jej cestu spät do konformity. Je zrejmé, že najmä v (metonymicky chápanej) celkovej rozhádanej dedine by mohla hlavná hrdinka čo najrýchlejšie stratit svoju ludskú slobodu a vel'kodušnost́. Ide teda o pocit úniku do nekonečna, neurčita, l’udskej samoty (až po stratu opôr), ale vel’mi dôležité sú na pude sebazáchovy aj určité stereotypy a konštantné veci v živote (mat’ svoj dom na konci cesty ako zmýšlajúci človek a nie ako robot). Je teda dôležité pochopit, že „... času je jedno, len mi plynieme, on je, my sa však míñame“ (s. 172).

Ako pendant ženských osudov a pocitov slúži v makrokompozícii textu súmerne zaradená čast̉ psychických pocitov Ivetinho manžela (ako druhá strana mince). On, z vlastného uhla pohladu akoby osamotený človek, znášajúci údely osudu vo väzení vlastného tela, hladajúci minulost’ v prítomnom pocite zrady vlastnej manželky, je vlastne odkázaný na všestrannú pomoc svojho okolia (najmä rodiny) aj pri uskutočnení vlastných snov, plánov, povinností. V tomto bezútešnom manželstve bez radosti sa v jeho osude konkretizuje myšlienka, že „... aj mašinka môže mat’ kedy-tedy defekty a čo viac, zošmyknuté ložiská môžu aj boliet" (s. 180). V tejto (mužskej) psychike je dôležitá aj túžba vykonat niečo hrdinské, pritom každodenné, v neustálej aktívnej činnosti. V tomto bode sa stretáva spomínaná ambivalentnost̉ nielen ženských, ale aj mužských typizovaných protagonistov.

Autorka na základe dejovej línie zdôrazňuje potrebu nájst’ si čas na komunikáciu s ostatnými l'ud'mi a zapadnút do retaze tradície so zachovaním osobnej špecifickosti: „... jej dávny obraz prikladá k jej dnešnej tvári [...] obraz milej učitel’ky predsa v ňom žiaril a utvrdzoval ho v domnienke, že sa podstata vecí netratí" (s. 186). Dôležitý je teda nekonečný kolobeh života z tmy do svetla a opačne, uvedomenie si podstaty a úlohy ochrany ženy na rodovom princípe (v sujete najmä pre deformáciu podstaty vztahu) a byt partnerom vo všetkom a nie trpiet. Ako dierézu v príbehu môžeme vnímat’ podanú žiadost̉ o rozvod kvôli nejasným okolnostiam a neusporiadanému životu v širšom časovom rozpätí. Podstatou toho je však nezapadnutie do prostredia a na začiatku absencia patričného zaradenia človeka do spoločenských konvencií. Je smutné, že „... dielo osobností doceňujeme vtedy, ked' sa pominú, 
lebo ho môžeme uchopit’ ako celok a správna usúvzt’ažnit’ každú jeho zložku. Tým mu prinavraciame hodnotu, tým mu rekonštruujeme nové, permanentné bytie“ (s. 215). A práve tento kolobeh vždy nového a nového bytia dáva jednotlivcovi nádej, že celý jeho život s osobnými vzt’ahmi mal, má a bude mat zmysel, ved' hladáme „... to isté. Len uhol pohl'adu je iný. Ale aj podstata pohladu je taká istá. Ludská. Vždy smerujeme $k$ realizovaniu rovnováhy človeka so svetom. Objektívej a subjektívej" (s. 178).

Ďalšia zbierka autorky s názvom Zväčšenina obsahuje pätnást́ prozaických textov (z toho dvanást̉ krátkych poviedok, ktoré už boli publikované najmä vo Variáciách, a tri širšie koncipované novely z autorkinej prozaickej pôvodiny - aj tu vidíme akúsi kontinuitu smerom k novému miléniu). V kratších prózach je evidentný širokospektrálny chronotop samotného času a priestoru. Občas sa príbeh odohráva v školskom prostredí (Modré štastie, Referát), ale aj v širšom okolí vlastného subjektu (Volanie, Rozprávka pre dospelých, Hrdost', Zväč̌senina). Didaktický príbeh hladného žiačika, ktorý za požičané peniaze kúpi jedlo aj pre svojho otca, skrýva v sebe prvoplánové didaktické podtóny. Je to zobrazená dnešná realita nejednej rodiny, kde je však vd’aka prízvukovanej dobrej výchove identifikovatelná obrovská (symbolická) kopa štastia. Takýto realistický až krutý obraz chudoby sa v širšom kontexte kompenzuje pseudoromantickým príbehom o antropomorfizovanej bielej husi. Tento zvierací stav je dostatočným okom kamery na identifikáciu neduhov l’udského sveta. Poznaním, že l'udský svet je vlastne zvierací, v ktorom „... bližšie tvoje pierko ako čiesi nebo a s krídlami d’alej zájdeš, ked’ poriadne dookola máchneš (do iných husí)..." (s. 10), sa čitatel' postupne oboznamuje s absurdnostou doby. Autorka prízvukuje dôležitost̉ pestovat dobrú výchovu, myslenie, pozorovanie a systematizovanie. Dôležitým symbolom, až medzníkom, je bludný kruh tmy, ktorá gniavi každé úsilie. Z nej vyvierajúci chlad nepomáha ani múdrosti. Autorka vidí konečný výsledok len v ceste vymanenia z tejto pustatiny. Je to svet, v ktorom vládne Vel'ká Hus ako nepolapitel’ná vyššia inštancia. Dôležité je však zachovat' si dobré úmysly, potrebnú odhodlanost’ a existenciu vlastného názoru ako znak tvorivej individuality. Podla autorky je najdôležitejšie svedomie, zachovanie všetkých ilúzií a mat aj svoje tajné miesto na útek. Zdôrazňuje pritom podstatu individuality, samo putovanie za pravdou, počas ktorého „... som l'ahšia, letím, strácam spojenie so zemou, unáša ma teplý prúd a vlečie ma kamsi, možno budem mat’ štastie..."(s. 17). Významný je explicitne prítomný psychologický podtón; ten sa konkretizuje napríklad najprv absurdne znejúcim úmyslom odmerat̉ stupeň úprimnosti jablka. Na základe toho je dôležitá zväčšenina každého obrazu nášho sveta, pomocou ktorej sa dá potom identifikovat červík v zdravom jablku. Tento prístup je aplikovatel'ný aj v konkrétnom l'udskom živote a prináša poznanie o l'ud'och i o našom okolí. Vedomosti človeka sú však redukované, lebo: „Ani kôstka v prostriedku nádherného ovocia nevie, aký pôvab ju zvonka obaluje“ (s. 21).

Spomínaná cesta pri hladaní štastia sa vyskytuje aj v osude mladej tlmočníčky, ktorá determinovaná svojím vekom sa dá vtiahnut do určitých bláznovstiev. Prirodzený pocit mladíckej nerozvážnosti dáva dynamický spád textu, ktorý vyjadruje potrebu si splnit sny aspoň v mladosti (byt hlavnou postavou dňa, stat’ sa v mysli námorníkom, vidiet’ cudzie kraje). Autorka zdôrazňuje silu vysloveného, ale aj napísaného slova, ktoré by malo byt etickým kódexom konania dospelých ludí. Toto morálne krédo je odrazovým mostíkom v psychologickom vývine mladého učitela, ktorý na školskej porade prečíta starý referát 
ako nový. Jeho postupný boj v podvedomí prízvukuje zretel’ný didaktický aspekt. V jeho pracovnom okolí sa dajú nájst' typizované osoby kolegov i riaditela. Najdôležitejšia je pohoda, metóda prežitia a „prežutia“. Šedivost̉ doby sa však vykresl’uje skutočnostou, že text rovnakého referátu nikto nespozná (učitelia opravujú písomky, lúštia krížovku a nakoniec tlieskajú). Dôležité je teda znovu získat skúsenosti pri vlastnom zistení toho, ako sa učitel'ovi „... rozšíril horizont vedomostí, ako sa naplnil dobrým pocitom, že je prospešný sebe a celému kolektívu..." (s. 32). Zdôrazňuje sa pritom aj na širšej ploche doba nacvičeného automatizmu a s tým spojené (ne)bytie slobody jednotlivca.

Ako paralelu ku školskému prostrediu autorka pridáva príbeh z artistického prostredia, miesta, kde za úsmevom sa skrýva kopa driny. Na druhej strane však poukazuje na tažké hladanie zmyslu celého toho napätia (výkonu artistu i samotného života). V pozadí všetkého je však konštatovanie o pominutel’nosti sveta z dôvodu l’udskej nekomunikácie. Autorka je však optimistka, hladiac ako dobrý gazda vždy do budúcnosti. Tá má v sebe aj zárodky tajomnosti ako zakopaný poklad. Tento fenomén je centrálnym bodom v poviedke Jano, publikovanej aj vo vojvodinskom časopise Nový život, v ktorom sa využíva epické rozprávanie s občasnými lyrickými vsuvkami. Anocová píše o potrebe volného času (dovolenky) v živote (večne pracujúceho) človeka a s tým súvisí pokoj v duši. Sen o starom otcovi je hnacím motorom príbehu, ktorého hlavnou dejovou líniou je tajomný motív zakopaného pokladu v záhrade (cesta do záhrady, samotné kopanie). Čarovné rozprávanie malému chlapcovi o starootcovskej čarovnej píštalke je alúziou na spoločne prežité časy v minulosti. Zdôrazňuje sa pritom potreba mat niekoho v živote rád. Sú to teda hodnoty, ktoré sú nevyčíslitel'né materiálnymi prostriedkami. Sviatočné, bezstarostné chvíle detstva, popretkávané tajomstvom tušeného prekvapenia a vytúžených darčekov, sa kladie na časovej osi do kontrastu so súčasnými, až príliš surovými pomermi (mladí prídu na Vianoce neskoršie, otec detí potrebuje vol’nost', napätie je zrejmé aj pri sviatočnom stole). V symbolike návratu k tomuto stolu a v pokore obrazu umývania nôh žobrákovi sa využíva alúzia biblického motívu v pozadí dôvery, dobromysel'nosti a nezištnosti. Dôležité je teda nájst̉ seba samého, duševný pokoj, ale aj chápanie reality, ktorá je často taká mrazivá ako cencúl' na vianočnom okne. Postupné zužovanie priestoru človeka sa deje najmä z dôvodu nadmernej civilizovanosti, nekomunikácie a neprívetivosti ludí. Tento stav deklaruje aj ohlušujúce ticho a smutný opis zimnej ulice: „... ovial ju sivý chlad. Steny potemneli od staroby, okná pohasli, hudba mlčala. Nikde ani živej duše“ (s. 237). Prenasledovanie človeka v takejto situácii je spredmetnením túžby po spomínanej debate s hocikým, čo však autorka „roztína“ až postmoderným obrazom práve prenasledovaného auta bez šoféra. Jeden z variantov adekvátnej socializácie v meste je nájst̉ si priatelov. Tento fakt sa skonkretizuje prelínaním skutočného a fantastického sveta z výtvarného obrazu. Realita doby je determinovaná šetrením prúdu a jeho prídelom. Tragikomickost’ sa vykryštalizuje snažením učitel'ky odpútat’ u starších žiakov pozornost̉ od tejto smutnej reality. Tieto determinanty zvýraznia psychickú labilitu mladíckej odhodlanosti voči profesii, ved' „... preklínala chvilu, ked' sa jej zamarilo, že je povolaná, predurčená byt' učitel'kou, že len tak sa jej osud naplní, ked' bude učit’ a viest’ deti k dokonalosti“ (s. 258-259). V̌̌dy je však prítomná duševná rovnováha a vnútorné spytovanie sa seba samého o pravdivosti vlastného konania. Dôležitá je teda exkurzia do ticha a identifikácia podvedomia. V tomto 
antisvete sa objavujú tradičné znaky postmoderny, ked' „... vypadla z koordinát súčasnosti a vybavil sa jej obraz chodby, po ktorej beži raz jedným smerom, raz opačným smerom. Pohyb je trhaný, vlastne pulzujúci“ (s. 261). Najdôležitejšie je však pozriet’ sa problémom do očí ako spôsob vyriešenia nespokojnosti a nepokoja. Svet je teda pestrofarebný: plný priatelov i nepriatel'ov, reality i fantastiky. Treba však nájst' svoju pravdu, konat ju a prispôsobovat sa jej v užšom i širšom okolí.

V jednotlivých textoch sa často objavuje aj motív smrti. Ten je konkretizovaný v konštelácii času, miesta, tradície. Tie majú zasa silný vplyv na životné osudy hrdinov, ktoré autorka uvádza napríklad klasickým odmietnutím oficiera - jeho prosby o ženbu. Život je teda symbolizovaný dvoma holubičkami, ktoré sú často smutné, až bez života. Prostredie starého dedinského cintorína je konečnou stanicou dlhej cesty človeka. Opis suchej trávy, zvädnutých kvetov a zarastených hrobov s mramorovými pomníkmi pôsobí úctyhodne voči spomínaným obyčajom. Tento starý svet sa dáva do kontrastu s neostýchavou civilizáciou súčasnosti. V impresionisticky ladenom texte autorka využíva plač osamoteného človeka za svojimi rodičmi. Takýmto oblúkom sa vlastne človek-milión dostáva na koniec svojej pozemskej cesty. Tak ako autor tohto príspevku na koniec svojej interpretácie.

\section{Literatúra}

ANDRUŠKA, Peter: Dolnozemské podoby slovenskej kultúry. Nitra: Univerzita Konštantína Filozofa v Nitre, 2007.

ANOCA, Dagmar Mária: Kniha príbehov alebo poltóny. Bukurešt: Kriterion, 1988.

ANOCA, Dagmar Mária: Slovenská literatúra v Rumunsku. Nadlak: Vydavatel'stvo Ivan Krasko, 2010. ANOCA, Dagmar Mária: Zväčšsenina. Nadlak: Vydavatel’stvo Ivan Krasko, 2001.

BABIAK, Michal: Literatúra a kontext. Nadlak: Vydavatel'stvo ESA - Vydavatel'stvo Kultúrnej a vedeckej spoločnosti Ivana Krasku, 1999.

CHMEL, Rudolf: Spoločnost’ a život literatúry. In: Romantizmus v globalizme. Bratislava: Kalligram, 2009, s. 212-215; resp. Slovenské pohlady 104, 1988, č. 1, s. 2-5.

BOTÍK, Ján: Dolnozemski Slováci. Nadlak: Vydavatel’stvo Ivan Krasko, 2011.

ČINČUROVÁ, Xénia: Epické podoby priestoru. Levoča: Modrý Peter, 2004.

HARPÁŇ, Michal: Skice k tvorivej podobizni Dagmar Márie Anocovej. In: Texty a kontexty. Bratislava: Literárne informačné centrum, 2004, s. 165-181.

KOVÁČOVÁ, Zuzana: Antropocentrizmus a archetypálnost’ v tradičnej frazéme a v originálnej metafore v poviedkach Dagmar Márie Anocovej z aspektu holistickej teórie jazyka. In: Svedectvá slovenského dolnozemského bytia - aspekty zo slovenskej dolnozemskej kultúrnej histórie a kultúrnej antropológie. Nadlak: Vydavatel'stvo Ivan Krasko, 2012, s. 143-149.

KOVÁČOVÁ, Zuzana: Jazykové aspekty dolnozemskej prózy (Interpretačná jazykovo-tematická analýza vybraných próz Dagmar Márie Anocovej). In: Svedectvá slovenskej dolnozemskej prózy. Nadlak: Vydavatel'stvo Ivan Krasko, 2011, s. 69-71.

RĂU-LEHOTSKÁ, Anna: Próza Dagmar Márie Anoca videná prizmou vzṫahov. In: Svedectvá slovenskej dolnozemskej prózy. Nadlak: Vydavatel’stvo Ivan Krasko, 2011, s. 89-91. 
ŠENKÁR, Patrik: Večné a podobné zrkadlenia „rozprávkového“ sveta „stredoeurópskych“ detí v intencionálnych prózach D. M. Anocovej a J. Nováka. In: POSPÍŠIL, Ivo (ed.): Střední Evropa včera dnes: proměny koncepcí II (jazyk - literatura - kultura - politika - filozofie). Brno: Středoevropské centrum slovanských studií, 2018.

ŠTEFANKO, Ondrej: Pohladaj korene svoje. Nadlak: Vydavatel'stvo Kultúrnej a vedeckej spoločnosti Ivana Krasku, 1998.

\section{doc. PaedDr. Patrik Šenkár, PhD.}

Katedra slovenského jazyka a literatúry Pedagogická fakulta, Univerzita J. Selyeho

Bratislavská cesta 3322, 94501 Komárno, Slovensko senkarp@ujs.sk 
